\title{
Changes in Intestinal and Hepatic Thyroid Hormone Deiodination During Spontaneous Metamorphosis of the Sea Lamprey, Petromyzon marinus
}

\author{
J. GEOFFREY EALES, ${ }^{1 *}$ JENNIFER M. MCLEESE, ${ }^{1}$ JOHN A. HOLMES ${ }^{2}$ \\ AND JOHN H. YOUSON ${ }^{2}$ \\ ${ }^{1}$ Department of Zoology, University of Manitoba, Winnipeg, Manitoba, R3T \\ 2N2, Canada \\ ${ }^{2}$ Division of Life Sciences, University of Toronto at Scarborough, Ontario, \\ M1C 1A4, Canada
}

\begin{abstract}
We measured microsomal low- $\mathrm{K}_{\mathrm{m}}$ outer-ring deiodination (ORD) and inner-ring deiodination (IRD) activities for thyroxine $\left(\mathrm{T}_{4}\right)$ and 3,5,3'-triiodothyronine $\left(\mathrm{T}_{3}\right)$ in intestine and liver in nonmetamorphosing (undersized) larvae, immediately premetamorphic larvae, animals in stages 1-7 of metamorphosis, and immediately postmetamorphic sea lampreys (Petromyzon marinus). For intestine: $\mathrm{T}_{4} \mathrm{ORD}$ activity was relatively low in nonmetamorphosing larvae, increased in premetamorphic individuals, was highest in stages 1 and 2 and was very low during stages 3-7; $\mathrm{T}_{4} \mathrm{IRD}$ activity was negligible until stage 3 but increased 4.7-fold through stages 3 to 7 such that $\mathrm{T}_{4} \mathrm{IRD}$ activity was 14 times $\mathrm{T}_{4} \mathrm{ORD}$ activity at stage $6 ; \mathrm{T}_{3} \mathrm{ORD}$ activity was undetectable; $\mathrm{T}_{3} \mathrm{IRD}$ activity was not measured through stages 3-7 but correlated with $\mathrm{T}_{4} \mathrm{IRD}$ activity at other stages. For liver: deiodination was only measured up to stage 2 and in postmetamorphic animals; in contrast to intestine, $\mathrm{T}_{4} \mathrm{ORD}$ activity fell to low levels at stage 2 and was low during postmetamorphosis; $\mathrm{T}_{4} \mathrm{IRD}$ and $\mathrm{T}_{3} \mathrm{IRD}$ activities were very low and uninfluenced by developmental stage; $\mathrm{T}_{3} \mathrm{ORD}$ activity was undetectable. We conclude that (1) deiodination activity is usually much higher in intestine than in liver, (2) intestinal ORD and IRD activities change reciprocally so that ORD predominates in early metamorphosis but IRD predominates in mid and late metamorphosis, and (3) changes in intestinal deiodination may contribute to the characteristic depression of plasma $\mathrm{T}_{4}$ and $\mathrm{T}_{3}$ levels during spontaneous metamorphosis. J. Exp. Zool. 286:305-312, 2000. @ ( 2000 Wiley-Liss, Inc.
\end{abstract}

Plasma levels of thyroid hormones (TH) undergo characteristic changes during lamprey metamorphosis. Plasma levels of both thyroxine $\left(\mathrm{T}_{4}\right)$ and 3,5,3'-triiodothyronine $\left(\mathrm{T}_{3}\right)$ peak in larval life and then decrease sharply as metamorphosis progresses (Wright and Youson, '77; Lintlop and Youson, '83a; Leatherland et al., '90; Youson et al., '94). This decrease may be necessary for metamorphosis (Youson, '97), since $\mathrm{T}_{3}$ has some effect in blocking the initiation of the event (Youson et al., '97). In at least some lamprey species, metamorphosis can be induced by potassium perchlorate which presumably depresses endostylar iodide uptake resulting in a decline in circulating $\mathrm{TH}$ levels (Hoheisel and Sterba, '63; Suzuki, '86; Holmes and Youson, '93; Youson et al., '95). This perchlorate-induced metamorphosis can also be blocked by maintaining high blood levels of TH (Manzon and Youson, '97; Manzon et al., '98). The cause of the natural fluctuations in blood TH levels during metamorphosis is unknown. It may involve changes in TH production by the metamorphosing larva, asso- ciated with the reorganization of the endostyle into the thyroid follicles (Wright and Youson, '76; Wright et al., '80), or it may involve changes in TH peripheral metabolism (Leatherland et al., '90).

In teleost fish, extrathyroidal deiodination is a major mechanism for regulating plasma TH levels (reviewed by Eales and Brown, '93; Mol et al., '97, '98). Changes in extrathyroidal deiodination could contribute to the changing profile of blood TH during lamprey metamorphosis. Induction of metamorphosis in the sea lamprey (Petromyzon marinus) by potassium perchlorate is not accompanied by a change in deiodination activity responsible for conversion of $\mathrm{T}_{4}$ to $\mathrm{T}_{3}$ (Manzon et al.,'98). However, to date there has been no thorough in-

Grant sponsor: Great Lakes Fishery Commission; Grant sponsor: Natural Sciences and Research Council of Canada.

*Correspondence to: J.G. Eales, Department of Zoology, University of Manitoba, Winnipeg, MB, R3T 2N2, Canada. E-mail: ealesjg@ ms.umanitoba.ca

Received 10 May 1999; Accepted 2 June 1999 
vestigation of deiodination during spontaneous metamorphosis of any lamprey species.

We therefore investigated the possibility that during spontaneous metamorphosis of laboratorymaintained sea lampreys, $P$. marinus, there are changes in the peripheral deiodination of TH that might explain the changes in blood TH levels. We examined the low- $\mathrm{K}_{\mathrm{m}} \mathrm{T}_{4}$ outer-ring deiodination (ORD) to produce $\mathrm{T}_{3}$ and, where material was available, we also examined the $\mathrm{T}_{4}$ inner-ring deiodination (IRD) to produce inactive $3,3^{\prime}, 5^{\prime}$-triiodothyronine $\left(\mathrm{rT}_{3}\right)$ and $\mathrm{T}_{3} \mathrm{IRD}$ to produce $3,3^{\prime}-$ diiodothyronine $\left(3,3^{\prime}-\mathrm{T}_{2}\right)$. In contrast to teleost fish, the intestine and not the liver is the main deiodination site in larvae and parasitic-stage lampreys (Eales et al., '97). We therefore focused on the intestine but we also examined liver when samples were available. The overall developmental profile was derived from three studies. In study I we analyzed metamorphic stages 3 to 7; in study II we analyzed postmetamorphic lampreys; in study III we analyzed nonmetamorphosing (undersized) larvae, immediately premetamorphic larvae and metamorphic stages 1 and 2 .

\section{MATERIALS AND METHODS Animal collection and maintenance}

\section{Study I}

Larval sea lampreys were collected on May 912, 1995 from Beaverdam Brook, a tributary of the Salmon River which drains into Lake Ontario, near Pulaski, New York. Larvae of $120 \mathrm{~mm}$ or longer and weighing at least $3.0 \mathrm{~g}$ were held in glass aquaria containing about $7 \mathrm{~cm}$ of sand and receiving a continous supply of running dechlorinated freshwater. Water tempertaure ranged from $15^{\circ} \mathrm{C}$ in early May to $21^{\circ} \mathrm{C}$ in mid-June to $15^{\circ} \mathrm{C}$ in mid-November. Lighting was fluorescent and the photoperiod was 15L:9D. Animals were fed baker's yeast once weekly at a ration of $1 \mathrm{~g}$ yeast/animal/ week. Animals were not fed during non-trophic metamorphosis. Metamorphosing animals $(\mathrm{n}=$ 18-30) corresponding to stages 3 to 7 of development (Youson and Potter, '79) were sampled periodically between August 15 and November 15, 1995. Each animal was anesthetized in $0.05 \%$ MS222 , weighed, measured and organs removed. The intestine was frozen at $-70^{\circ} \mathrm{C}$ for deiodination analysis.

\section{Study II}

Larvae were collected on May 31 and June 1, 1996 from Oshawa Creek, a tributary of Lake
Ontario, near Toronto, and used in an experiment to determine extreme and optimal temperatures for metamorphosis (Holmes and Youson, '98). The animals that entered metamorphosis were pooled on August 15, 1996, and held without food under the conditions described for study I. By December 20-25, 1996, young fully metamorphosed parasitic juveniles (hereafter referred to as postmetamorphic animals) began emerging from the sand. They were held without food until they were sampled ( $\mathrm{n}=20)$ on January 28, 1997.

\section{Study III}

Larvae were collected on May 13-15, 1998, from Fish Creek, New York, and held in the laboratory under the conditions described in study I at 14$16^{\circ} \mathrm{C}$. Beginning on June 1 , water temperature was raised by $1^{\circ} \mathrm{C} /$ day to $21^{\circ} \mathrm{C}$ and then held at this level. On June 8 we sampled 18 premetamorphic larvae $(>120 \mathrm{~mm},>3.0 \mathrm{~g}$, condition factor $(\mathrm{CF})$ $>1.50$ ) which were predicted, on the basis of size and $\mathrm{CF}$, to initiate metamorphosis in about 1 month (Youson et al., '93). On June 23 we sampled 20 larvae $(<120 \mathrm{~mm},<3.0 \mathrm{~g})$ that were predicted, on the basis of size, would not metamorphose; hereafter this undersized group is referred to as nonmetamorphosing larvae. On July 14, approximately 1-1.5 weeks after the start of metamorphosis, we sampled 10 animals in each of stages 1 and 2.

\section{Study IV}

This study represents previously published data (Eales et al., '97) on the adult feeding period. We included it here to provide a complete view of the life cycle from larva to feeding adult.

\section{Deiodination analyses}

Microsomal fractions were prepared (Shields and Eales, '86) as pools from four (study I) or two (Studies II and III) individuals at the same development stage and stored at $-76^{\circ} \mathrm{C}$. Deiodination assays were run on the microsomal fractions using $0.11-0.18$ (study I), $0.25-0.4$ (study II) or $0.1-$ 0.4 (study III) $\mathrm{mg}$ of microsomal protein $/ \mathrm{ml}$ incubate. The assay method followed that of Johnston and Eales ('95) and was conducted at $12^{\circ} \mathrm{C}$, at $\mathrm{pH} 7.2$, with $10 \mathrm{mM}$ dithiothreitol (DTT) for an incubation of $2 \mathrm{hr}$, using high-specific activity $\left[{ }^{125} \mathrm{I}\right] \mathrm{T}_{4}$ or $\left[{ }^{125} \mathrm{I}\right] \mathrm{T}_{3}$ (New England Nuclear) as substrate. The end-products were analyzed by HPLC (Sweeting and Eales, '92). No unlabelled substrate was added to the labelled stock substrate provided by the manufacturer. This proce- 
dure was followed to maximize conversion of labelled substrate for the purpose of HPLC detection. Changes in specific activity of the stock material resulted in small variations in substrate level between studies. In order to compare between studies, all deiodinase activities were corrected for a common substrate level of $0.15 \mathrm{nM}$, assuming that over the narrow substrate range used in the different studies, deiodination activity would be proportional to substrate concentration. $\mathrm{T}_{4} \mathrm{ORD}$ activity was assessed from formation of labelled $\mathrm{T}_{3}, \mathrm{~T}_{4} \mathrm{IRD}$ activity from formation of $3,3^{\prime}, 5^{\prime}$-triiodothyronine $\left(\mathrm{rT}_{3}\right), \mathrm{T}_{3} \mathrm{ORD}$ activity from formation of radioiodide and $\mathrm{T}_{3} \mathrm{IRD}$ activity from formation of $3,3^{\prime}-\mathrm{T}_{2}$. Deiodination activity was expressed as fmols $\mathrm{T}_{4}$ or $\mathrm{T}_{3}$ deiodinated/hr/mg microsomal protein.

\section{Statistical analyses}

Within each of studies I and III the effect of stage of development was determined by one-way ANOVA. If a significant $(P<0.05)$ difference was found, individual means were then compared by Student-Neuman-Keuls test $(P<0.05)$.

\section{RESULTS}

Table 1 gives sampling dates and mean values for body length, body mass and condition factor for studies I, II, and III.

\section{Intestine}

$\mathrm{T}_{4} \mathrm{ORD}$ activity (Fig. 1A) was significantly higher in stages 1 and $2(\approx 40 \mathrm{fmols} / \mathrm{hr} / \mathrm{mg})$ than in nonmetamorphosing larvae ( $7 \mathrm{fmols} / \mathrm{hr} / \mathrm{mg}$ ). However, $\mathrm{T}_{4} \mathrm{ORD}$ activity was low at stage 3 (3 fmols $/ \mathrm{hr} / \mathrm{mg}$ ) and did not change significantly to stage 7 or during postmetamorphosis. $\mathrm{T}_{4} \mathrm{IRD}$ activity (Fig. 1B) was negligible until stage 3 (15 fmols/hr/mg) but increased during metamorphosis to $70 \mathrm{fmols} / \mathrm{hr} / \mathrm{mg}$ at stage 7 , and was still appreciable (19 fmols/hr/mg) during postmetamorphosis. The ratio of $\mathrm{T}_{4} \mathrm{IRD} / \mathrm{T}_{4} \mathrm{ORD}$ activities (Fig. $1 \mathrm{C})$ rose to a peak $(\approx 14: 1)$ during stages 6 and 7. Representative HPLC radiochromatograms (Fig. 2) show through stages 3 to 7 , the low $\mathrm{T}_{3}$ formation by $\mathrm{T}_{4} \mathrm{ORD}$ but the considerable $\mathrm{rT}_{3}$ formation by $\mathrm{T}_{4} \mathrm{IRD}$.

$\mathrm{T}_{3} \mathrm{ORD}$ activity was undetectable (Fig. 3B). $\mathrm{T}_{3}$ IRD activity (Fig. 1D) was not measured from stages 3-7 due to insufficient material. However, $\mathrm{T}_{3} \mathrm{IRD}$ activity tracked $\mathrm{T}_{4} \mathrm{IRD}$ activity in that it was negligible in nonmetamorphosing larvae, premetamorphic larvae and stages 1 and 2, but was appreciable in postmetamorphic lampreys (21 fmols/hr/mg) (Fig. 1D).

\section{Liver}

Liver $\mathrm{T}_{4} \mathrm{ORD}$ activity (10 fmols/hr/mg) (Fig. 4A) was comparable to intestinal $\mathrm{T}_{4} \mathrm{ORD}$ activity in nonmetamorphosing larvae (7 fmols/hr/mg) but fell significantly to $1.5 \mathrm{fmols} / \mathrm{hr} / \mathrm{mg}$ ) by stage 2 . $\mathrm{T}_{4} \mathrm{ORD}$ activity was not measured for stages $3-7$, but was low ( $1 \mathrm{fmol} / \mathrm{hr} / \mathrm{mg}$ ) at postmetamorphosis. $\mathrm{T}_{4} \mathrm{IRD}$ and $\mathrm{T}_{3} \mathrm{IRD}$ activities were very low $(\leq 2$ fmols/hr/mg) for all developmental stages examined (Figs. 3B, C and 4B, C). $\mathrm{T}_{3} \mathrm{ORD}$ activity was undetectable (Fig. 3C).

TABLE 1. Metamorphic stages, sampling dates, lengths, weights, and condition factors of the larvae or postmetamorphic (PM) lampreys used in studies I, II and III ${ }^{1}$

\begin{tabular}{lcccr}
\hline Stage & Date & Length $(\mathrm{mm})$ & Weight $(\mathrm{g})$ & Condition factor $^{2}$ \\
\hline Study I & & & & \\
3 & $8 / 15 / 95$ & $130.8 \pm 1.85$ & $4.16 \pm 0.18$ & $1.84 \pm 0.05$ \\
4 & $8 / 16 / 95$ & $126.8 \pm 1.84$ & $3.76 \pm 0.16$ & $1.82 \pm 0.02$ \\
5 & $8 / 16 / 95$ & $129.6 \pm 1.93$ & $3.85 \pm 0.16$ & $1.74 \pm 0.02$ \\
6 & $9 / 12 / 95$ & $130.0 \pm 1.94$ & $3.52 \pm 0.16$ & $1.62 \pm 0.02$ \\
7 & $11 / 14 / 95$ & $135.5 \pm 2.36$ & $3.45 \pm 0.17$ & $1.36 \pm 0.02$ \\
Study II $^{3}$ & & & & 18 \\
PM $^{3}$ & $1 / 28 / 97$ & $143.7 \pm 2.29$ & $3.64 \pm 0.15$ & 30 \\
Study III $^{4}$ & & & & $1.22 \pm 0.02$ \\
PR $^{5}$ & $6 / 23 / 98$ & $104.9 \pm 1.89$ & $1.95 \pm 0.09$ & $1.68 \pm 0.02$ \\
1 & $6 / 08 / 98$ & $132.7 \pm 1.59$ & $3.64 \pm 0.15$ & $1.54 \pm 0.03$ \\
2 & $7 / 14 / 98$ & $140.7 \pm 4.21$ & $4.61 \pm 0.38$ & $1.63 \pm 0.03$ \\
\hline
\end{tabular}

${ }^{1}$ Means \pm SEM.

${ }^{2}$ Condition factor $=\left[\mathrm{M}(\mathrm{g}) /\right.$ /iter $\left.(\mathrm{mm})^{3}\right] \times 10^{6}$.

${ }^{3}$ Postmetamorphic lampreys.

${ }^{4}$ Nonmetamorphosing larvae.

${ }^{5}$ Premetamorphic larvae. 


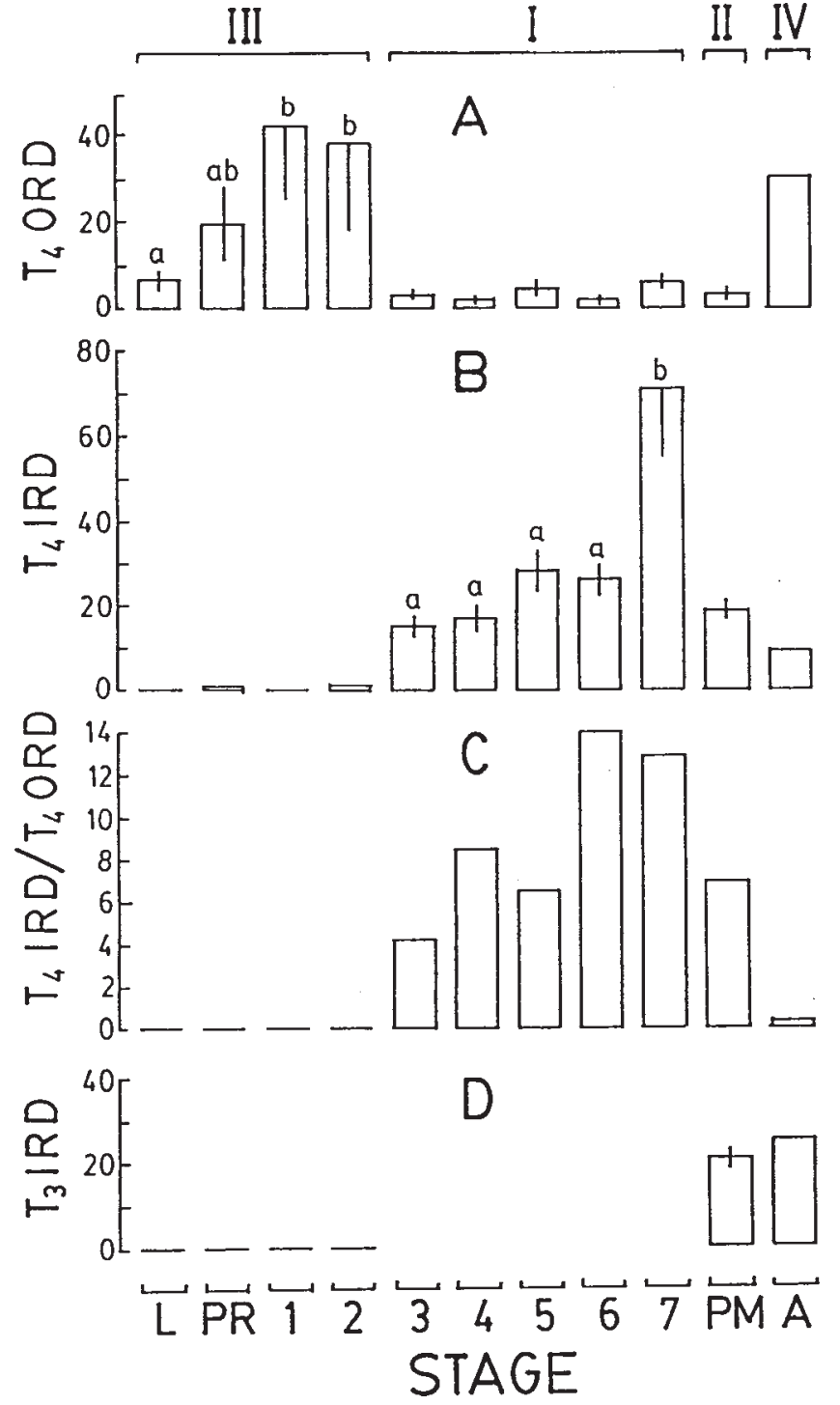

Fig. 1. Intestinal deiodination activities during lamprey development (means \pm SEM; $\mathrm{n}=5-10)$. (A) $\mathrm{T}_{4} \mathrm{ORD}$; (B) $\mathrm{T}_{4} \mathrm{IRD}$; (C) Ratio of $\mathrm{T}_{4} \mathrm{IRD}$ to $\mathrm{T}_{4} \mathrm{ORD}$; (D) $\mathrm{T}_{3} \mathrm{IRD}$. The profiles were derived from three studies in 1995 (I), 1997 (II), and 1998 (III) and also from Eales et al. ('97) (IV). L = nonmetamorphosing larvae; PR = premetamorphic larvae; $1-7$ = stages of metamorphosis; $\mathrm{PM}=$ postmetamorphic lampreys; $\mathrm{P}=$ parasitic lampreys. There was a significant effect of stage of development on $\mathrm{T}_{4} \mathrm{ORD}$ (study III) and $\mathrm{T}_{4} \mathrm{IRD}$ activity (study I). Within a given study, means with similar letters do not differ significantly $(P<0.05)$.

\section{DISCUSSION}

We showed previously in nonmetamorphosing sea lamprey larvae that $\mathrm{T}_{4} \mathrm{ORD}$ activity was higher in intestine than in liver, kidney or muscle and that $\mathrm{T}_{4} \mathrm{IRD}, \mathrm{T}_{3} \mathrm{ORD}$ and $\mathrm{T}_{3} \mathrm{IRD}$ activities were undetectable in any of these tissues (Eales et al., '97). We also found $\mathrm{T}_{4} \mathrm{ORD}, \mathrm{T}_{4} \mathrm{IRD}$ and $\mathrm{T}_{3} \mathrm{IRD}$ ac-

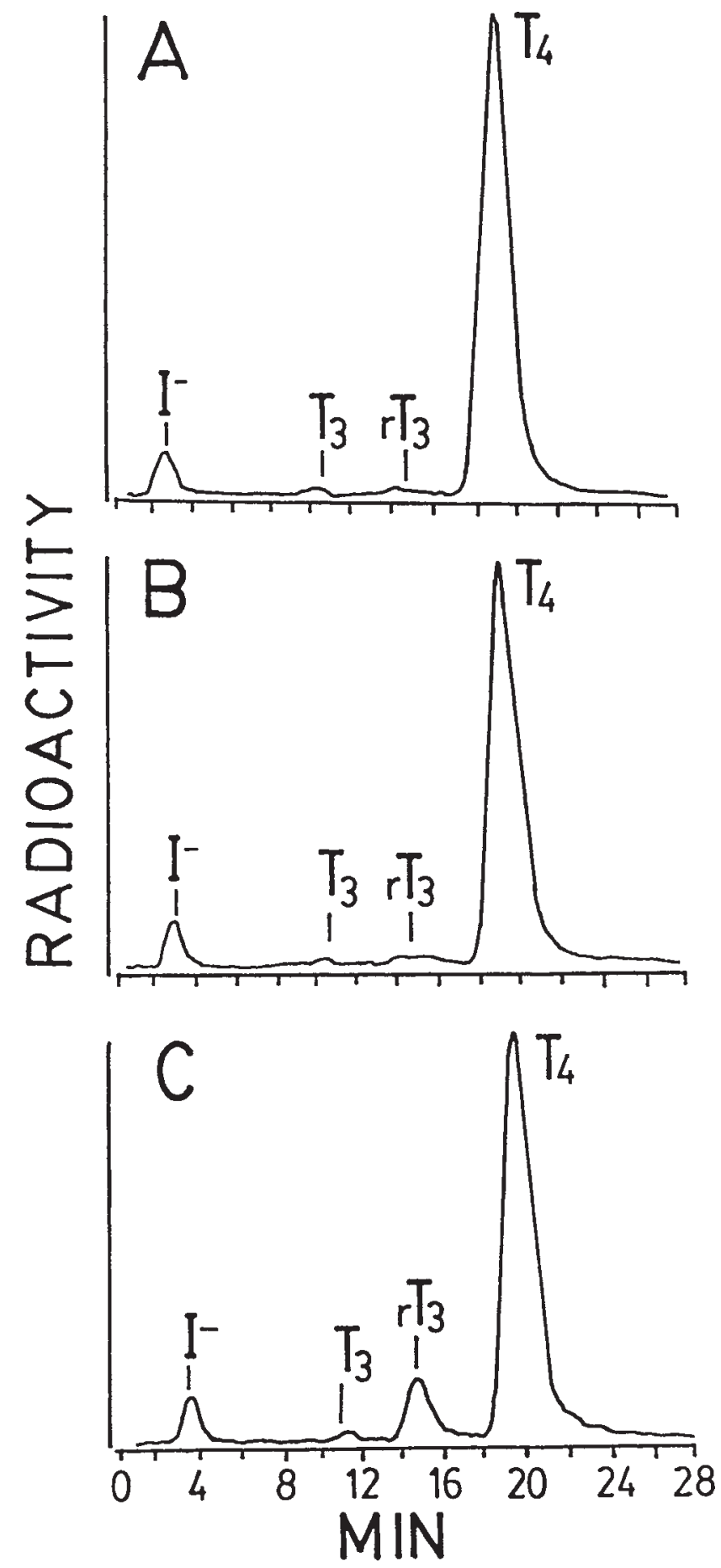

Fig. 2. HPLC radioactivity profiles for extracts of incubates of $\left[{ }^{125} \mathrm{I}\right] \mathrm{T}_{4}$ and microsomes from larval lamprey intestine. Retention times of UV-detected authentic $\mathrm{T}_{4}, \mathrm{~T}_{3}$ and $\mathrm{rT}_{3}$ are shown; $\mathrm{I}^{-}$, radioiodide. HPLC conditions: C-18 $150 \times 4.6-$ $\mathrm{mm}$ Econosphere column at $30^{\circ} \mathrm{C}$; isocratic elution with $38 \%$ acetonitrile with $0.1 \%$ trifluoroacetic acid (TFA)/62\% water with $0.1 \%$ TFA. (A) Control (no microsomes); (B) stage 3; (C) stage 7 . 


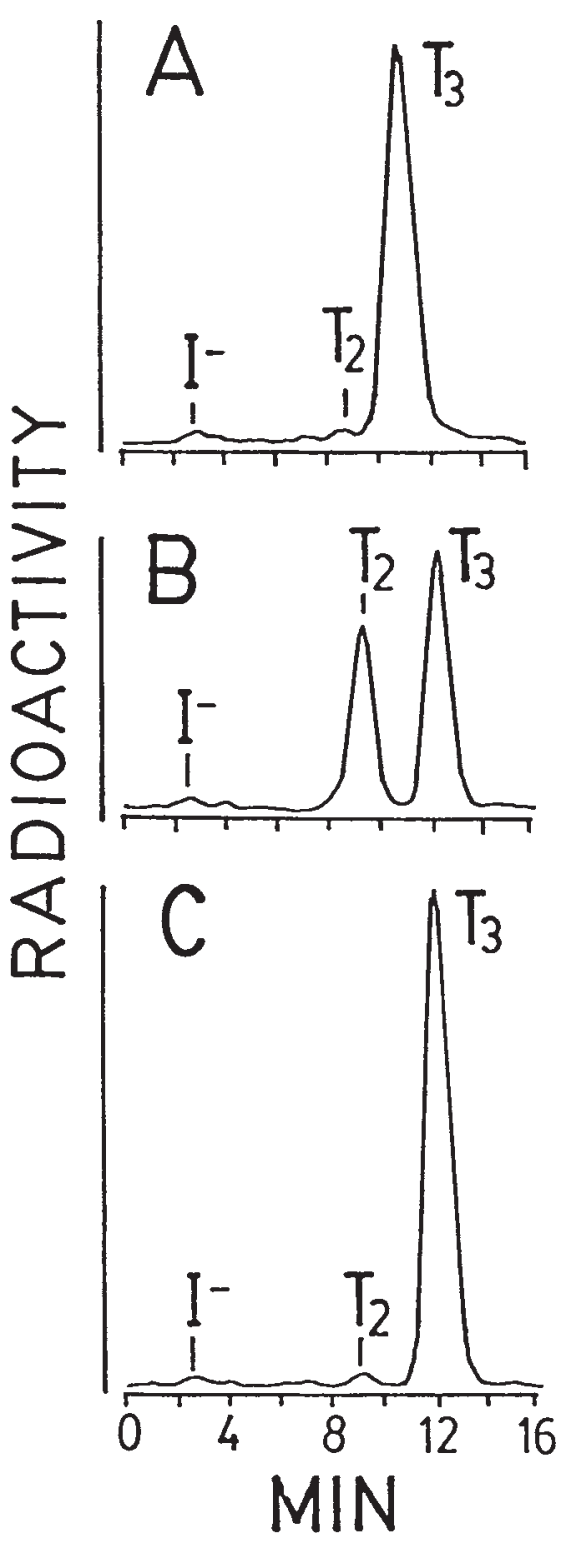

Fig. 3. HPLC radioactivity profiles for extracts of incubates of $\left[{ }^{125} \mathrm{I}\right] \mathrm{T} 3$ and microsomes from postmetamorphic lamprey tissues. Retention times of UV-detected authentic $\mathrm{T}_{3}$ and 3,3'- $\mathrm{T}_{2}$ are shown; $\mathrm{I}^{-}$, radioiodide. HPLC conditions: C-18 150 $\times 4.6-\mathrm{mm}$ Econosphere column at $30^{\circ} \mathrm{C}$; acetonitrile $(0.1 \%$ TFA)/water (0.1\% TFA) isocratic from 0-10 min, increasing linearly to $47 \%$ acetontrile at $14 \mathrm{~min}$ and then decreasing to $42 \%$ acetonitrile at $16 \mathrm{~min}$. (A) Control (no microsomes); (B) intestine; (C) liver.

tivities in intestine of metamorphosed parasiticstage lampreys, but low or negligible deiodinating activities in other tissues. We therefore focused here on intestinal deiodination, but we also examined liver when it was available. Our present data confirm that the intestine usually has more deiodinating activity than the liver. Only in

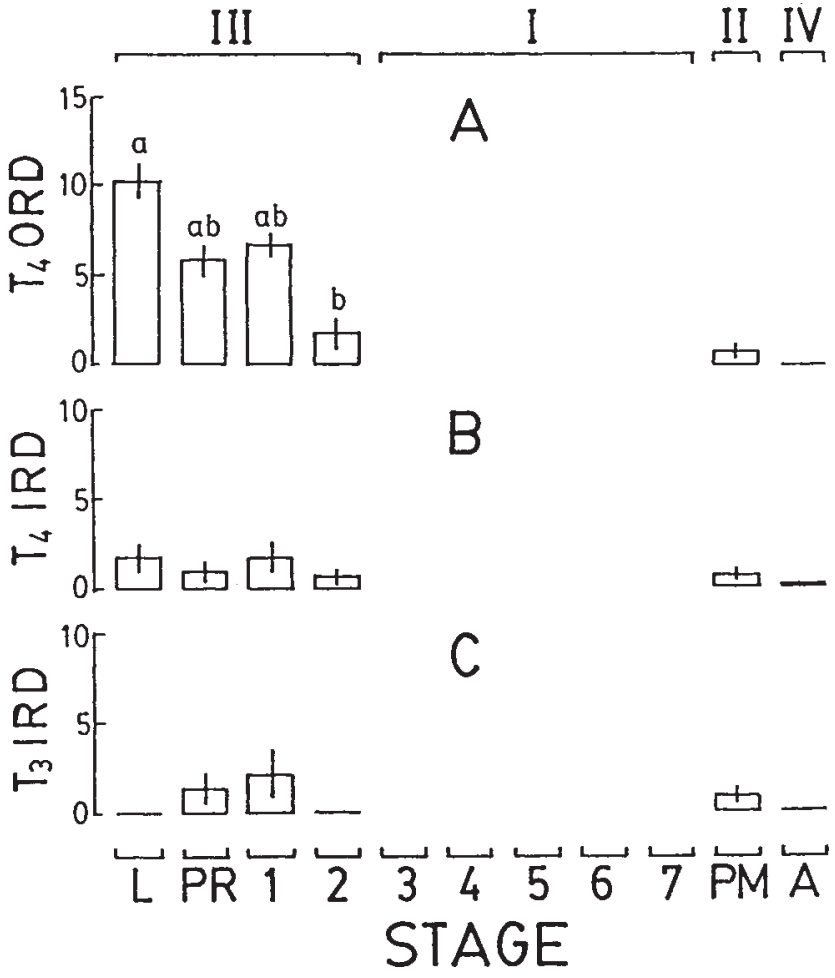

Fig. 4. Liver deiodination activities during lamprey development (means \pm SEM; $\mathrm{n}=5-10$ ). (A) $\mathrm{T}_{4} \mathrm{ORD}$; (B) $\mathrm{T}_{4} \mathrm{IRD}$; (C) $\mathrm{T}_{3} \mathrm{IRD}$. The profiles were derived from three studies in 1995 (I), 1997 (II), and 1998 (III) and also from Eales et al. ('97) (IV). L = nonmetamorphosing larvae; PR = premetamorphic larvae; $1-7$ = stages of metamorphosis; $\mathrm{PM}=$ postmetamorphic lampreys; $\mathrm{P}=$ parasitic lampreys. There was a significant effect of stage of development on $\mathrm{T}_{4} \mathrm{ORD}$ (study III). Within study III, means with similar letters do not differ significantly $(P<0.05)$.

nonmetamorphosing larvae was liver $\mathrm{T}_{4} \mathrm{ORD}$ activity comparable to that of intestine. At other developmental stages deiodination activity was considerably greater for intestine than liver.

In order to compare liver and intestine at different developmental stages, all our in vitro estimates of deiodination activity were based on a $\mathrm{TH}$ substrate level of $0.15 \mathrm{M}$. The activity values we report therefore represent the deiodinating potential of the tissues at this standardized TH concentration. The actual amount of TH deiodinated by these tissues in vivo will of course depend on the intracellular concentrations of the appropriate $\mathrm{TH}$ substrates, which were not measured in this study.

Our survey of deiodinating activity during development from the nonmetamorphosing larva to the parasitic-stage adult indicates a reciprocal relationship between intestinal $\mathrm{T}_{4} \mathrm{ORD}$ and $\mathrm{T}_{4} \mathrm{IRD}$ 
activities. Intestinal $\mathrm{T}_{4} \mathrm{ORD}$ activity is low in nonmetamorphosing larvae, reaches a peak during premetamorphosis and early metamorphosis, and then drops dramatically during metamorphosis to eventually rise again in parasitic-stage lampreys. Indeed the level of $\mathrm{T}_{4} \mathrm{ORD}$ activity during premetamorphosis is likely higher than that described here since it is only possible to select immediately premetamorphic larvae with $60-80 \%$ accuracy (Youson et al., '93; Holmes et al., '94). In contrast, $\mathrm{T}_{4} \mathrm{IRD}$ activity is negligible until stage 3 . It then climbs to a peak value at stage 7 but falls to modest levels in parasitic-stage lampreys. $\mathrm{T}_{3} \mathrm{IRD}$ activity was not measured during stages 3-7 due to insufficient material, but at all other stages $\mathrm{T}_{3} \mathrm{IRD}$ activity closely tracked $\mathrm{T}_{4} \mathrm{IRD}$ activity. This is expected if there is a common enzyme, comparable to the mammalian type III, that deiodinates both $\mathrm{T}_{4}$ and $\mathrm{T}_{3}$ from the inner ring. We conclude that during the initiation of metamorphosis (including before external signs are apparent) there is a major increase in intestinal $T_{3}$ production, followed by a shutdown of $\mathrm{T}_{4}$ conversion to $\mathrm{T}_{3}$ and a major induction of IRD of both $\mathrm{T}_{4}$ and $\mathrm{T}_{3}$ during mid metamorphosis. The biological significance of these changes in deiodination activity cannot be determined from this study. They could contribute to tissue-specific local regulation of thyroidal status as suggested for metamorphosing amphibia by Becker et al., ('97). They could also contribute to both the high plasma levels of $\mathrm{T}_{4}$ and $\mathrm{T}_{3}$ immediately prior to metamorphosis and the dramatic fall in these levels during metamorphosis (Wright and Youson, '77; Lintlop and Youson, '83a; Leatherland et al., '90; Youson et al., '94, '97).

Liver $\mathrm{T}_{4} \mathrm{ORD}$ activity was significantly lower in stage-2 larvae than in nonmetamorphosing larvae, suggesting that during the early stages of metamorphosis there is a decrease in hepatic $\mathrm{T}_{3}$ production by $\mathrm{T}_{4} \mathrm{ORD}$. In contrast intestinal $\mathrm{T}_{4} \mathrm{ORD}$ activity increased from nonmetamorphosing larvae to stage-2 larvae so that $\mathrm{T}_{4} \mathrm{ORD}$ activity of the intestine at stage 2 was 20 times that of liver. Although there could be changes in deiodinating activity in tissues that we did not examine, our data suggest that as larvae enter metamorphosis the intestine is the predominant peripheral deiodination site.

Metamorphosis can be induced prematurely by $\mathrm{KClO}_{4}$ treatment that also depresses plasma $\mathrm{T}_{4}$ and $\mathrm{T}_{3}$ levels (Youson et al., '95; Manzon and Youson, '97), but does not alter intestinal $\mathrm{T}_{4} \mathrm{ORD}$ activity (Manzon et al., '98). Thus there is a dif- ference in the intestinal $\mathrm{T}_{4} \mathrm{ORD}$ activity during $\mathrm{KClO}_{4}$-induced and spontaneous metamorphosis. However, during $\mathrm{KClO}_{4}$ treatment the decline in plasma $\mathrm{T}_{4}$ is likely due to decreased $\mathrm{T}_{4}$ production by the endostyle, and the decline in $\mathrm{T}_{3}$ is likely due to deficiency of $\mathrm{T}_{4}$ substrate to form $\mathrm{T}_{3}$. Furthermore, IRD pathways were not measured in our previous treatment with $\mathrm{KClO}_{4}$. These pathways could have contributed to the decline of both plasma $\mathrm{T}_{4}$ and $\mathrm{T}_{3}$.

Our present correlative study shows that changes in intestinal deiodination could explain the metamorphic decline in plasma TH levels. However, other factors may contribute to changes in plasma TH levels (Youson, '97). There could be decreased production of TH from the larval endostyle, which during metamorphosis undergoes structural reorganization to form the follicular thyroid characteristic of the parasitic stage (Wright and Youson, '76; Wright et al., '80). However, the transforming endostylar tissue continues to be capable of incorporation of radioiodine (Wright and Youson, 76). There is also some suggestion for increased binding capacity of thyroid hormone receptors for $\mathrm{T}_{3}$ in at least one tissue (Lintlop and Youson, '83b). It is possible, therefore, that changes in intestinal deiodination work in concert with other mechanisms and result in a lowering of plasma TH levels during lamprey metamorphosis.

The high deiodinating activity in the intestine of lamprey larvae may reflect the route whereby TH normally enter the larval circulation. Endostylar secretions containing thyroid hormones may be discharged to the gastrointestinal tract and absorbed from there into the blood (reviewed by Eales, '97). The intestine is therefore strategically placed to regulate the levels of $\mathrm{TH}$ delivered to the blood. However, during metamorphosis this mechanism could be greatly impaired as the entire alimentary canal undergoes a reorganization (Youson and Connelly, '78). This restructuring also involves the intestinal epithelium (Youson and Horbert, '82). Despite these changes, the intestine seems to be efficient in deiodination.

It is interesting to compare larval lamprey deiodination profiles with those of amphibians in which high levels of TH are required for the tadpole-to-frog metamorphosis (Galton, '88). At the start of lamprey metamorphosis $\mathrm{T}_{4} \mathrm{ORD}$ activity is high and both plasma $\mathrm{T}_{4}$ and $\mathrm{T}_{3}$ levels are high so that $\mathrm{TH}$ could be involved in the initiation of metamorphosis. However, in contrast to amphibian metamorphosis, morphological and physiological changes in lamprey metamorphosis correspond 
with a decrease and not an increase in plasma TH levels. Nevertheless, in both lampreys and amphibians, changes in ORD and IRD pathways feature prominently in the regulation of thyroidal status and the intestine is a major deiodination site (Galton and Hiebert, '87, '88; Becker et al., '97). Deiodination also occurs in amphibian skin (Galton and Hiebert, '88; Becker et al., '97) but has not yet been studied in lamprey skin. $\mathrm{T}_{4} \mathrm{IRD}$ has been reported for trout skin (Fenton et al., '97).

Significant intestinal $\mathrm{T}_{4}$ and $\mathrm{T}_{3} \mathrm{IRD}$, but undetectable levels of hepatic $\mathrm{T}_{4}$ and $\mathrm{T}_{3}$ ORD and IRD activities, have been reported in lampreys in the parasitic period (stage IV; Eales et al., '97). Therefore the immediately postmetamorphic state may represent the condition that persists into the feeding phase of adult life. During the parasitic period, when the sanguivorous lamprey may be ingesting significant amounts of $\mathrm{TH}$ from its host, the intestinal inner-ring pathways that degrade $\mathrm{TH}$ may be important in regulating entry of $\mathrm{TH}$ to the circulation.

Negligible $\mathrm{T}_{3} \mathrm{ORD}$ activity was observed in intestine or liver at any stage of development. This is consistent with previous observations on the sea lamprey (Eales et al., '97), teleost fish (Eales and Brown, '93; Mol et al., '97, '98) and higher vertebrates (McNabb, '92).

We conclude that IRD is induced during sea lamprey metamorphosis, and that this event in conjunction with depressed $\mathrm{T}_{4} \mathrm{ORD}$ activity may contribute to the decrease in plasma $\mathrm{TH}$ levels which is so characteristic of early metamorphosis and which may be required for the event to proceed.

\section{ACKNOWLEDGMENTS}

This study was supported primarily by a contract from the Great Lakes Fishery Commission to J.H.Y. and also by research grants from the Natural Sciences and Research Council of Canada to J.H.Y. and J.G.E.

\section{LITERATURE CITED}

Becker KC, Stephens KC, Davey JC, Schneider MJ, Galton VA. 1997. The type 2 and type 3 deiodinases play important roles in coordinating development in Rana catesbeiana tadpoles. Endocrinology 138:2984-2997.

Eales JG. 1997. Iodine metabolism and thyroid-related functions in organisms lacking thyroid follicles. Are thyroid hormones also vitamins? Proc Soc Exp Biol Med 214:302-317.

Eales JG, Brown SB. 1993. Measurement and regulation of thyroidal status in teleost fish. Rev Fish Biol Fisheries 3:299-347.

Eales JG, Holmes JA, McLeese JM, Youson JH. 1997. Thy- roid hormone deiodination in various tissues of larval and upstream-migrant sea lampreys, Petromyzon marinus. Gen Comp Endocrinol 106:202-210.

Fenton B, Orozco A, Valverde RC. 1997. Kinetic characterization of skin inner-ring deiodination pathway and its correlation with circulating levels of reverse triiodothyronine in developing rainbow trout. J Endocrinol 154:547-554.

Galton VA. 1988. The role of thyroid hormone in amphibian metamorphosis. Am Zool 28:309-318.

Galton VA, Hiebert A. 1987. Hepatic iodothyronine 5deiodinase activity in Rana catesbeiana tadpoles at different stages of the life cycle. Endocrinology 121:42-47.

Galton VA, Hiebert A. 1988. The ontogeny of iodoythyronine 5 -monodeiodinase activity in Rana catesbeiana tadpoles. Endocrinology 122:640-645.

Hoheisel G, Sterba G. 1963. Uber die Wirkung von Kaliumperchlorat $\left(\mathrm{KClO}_{4}\right)$ auf Ammocoeten von Lampetra planeri. Bloch Z Mikrosk Anat Forsch 70:490-516.

Holmes JA, Youson JH. 1993. Induction of metamorphosis in landlocked sea lampreys, Petromyzon marinus. J Exp Zool 267:598-604.

Holmes JA, Youson JH. 1998. Extreme and optimal temperatures for metamorphosis in sea lampreys. Trans Am Fish Soc 127:206-211.

Holmes JA, Beamish FWH, Seelye JG, Sower SA, Youson JH. 1994. The long-term influence of water temperature, photoperiod and food availability on metamorphosis of sea lampreys, Petromyzon marinus. Can J Fish Aquatic Sci 51: 2045-2051.

Johnston CE, Eales JG. 1995. Effects of acclimation and assay temperature on outer- and inner-ring thyroxine and $3,5,3^{\prime}$-deiodination by liver microsomes of rainbow trout, Oncorhynchus mykiss. J Exp Zool 272:426-434.

Leatherland JF, Hilliard RW, Macey DJ, Potter IC. 1990. Changes in serum thyroxine and triiodothyronine concentrations during metamorphosis of the Southern Hemisphere lamprey, Geotria australis, and the effect of propylthiouracil, triiodothyronine and environmental temperature on serum thyroid hormone concentrations of ammocoetes. Fish Physiol Biochem 8:167-177.

Lintlop SP, Youson JH. 1983a. Concentration of tri-iodothyronine in the sera of the sea lamprey, Petromyzon marinus, and the brook lamprey, Lampetra lamottenii at various phases of their life cycle. Gen Comp Endocrinol 49:187-194.

Lintlop SP, Youson JH. 1983b. Binding of tri-iodothyronine to hepatocyte nuclei from sea lamprey, Petromyzon marinus L., at various stages of the life cycle. Gen Comp Endocrinol 49:428-436.

Manzon RG, Youson JH. 1997. The effects of exogenous thyroxine $\left(\mathrm{T}_{4}\right)$ or triiodothyronine $\left(\mathrm{T}_{3}\right)$, in the presence and absence of potassium perchlorate, on the incidence of metamorphosis and on serum $\mathrm{T}_{4}$ and $\mathrm{T}_{3}$ concentrations in larval sea lampreys (Petromyzon marinus). Gen Comp Endocrinol 106:211-220.

Manzon RG, Eales JG, Youson JH. 1998. Blocking of $\mathrm{KClO}_{4}{ }^{-}$ induced metamorphosis in premetamorphic sea lampreys by exogenous thyroid hormones (TH); effects of $\mathrm{KClO}_{4}$ and $\mathrm{TH}$ on serum $\mathrm{TH}$ concentration and intestinal outer-ring deiodination. Gen Comp Endocrinol 112:54-62.

McNabb FM. 1992. Thyroid hormones. Englewood Cliffs, NJ: Prentice Hall.

Mol KA, Van Der Geyten S, Darras VM, Visser TJ, Kuhn ER. 1997. Characterization of iodothyronine outer ring and inner ring deiodinase activities in the blue tilapia, Oreochromis aureus. Endocrinology 138:1787-1793. 
Mol KA, Van Der Geyten S, Burrel C, Kuhn ER, Boujard T, Darras VM. 1998. Comparative study of iodothyronine outer ring and inner ring deiodinase activities in five teleostean fishes. Fish Physiol Biochem 18:253-266.

Shields CA, Eales JG. 1986. Thyroxine 5'-monodeiodinase activity in hepatocytes of rainbow trout, Salmo gairdneri: distribution, effects of starvation and exogenous inhibitors. Gen Comp Endocrinol 63:334-343.

Suzuki S. 1986. Induction of metamorphosis and thyroid function in the larval lamprey. In: Mederios-Neto G, Gaiten E, editors. Frontiers of thyroidology, vol. I. New York: Plenum. p 667-670.

Sweeting RM, Eales JG. 1992. HPLC analysis of in vitro hepatic deiodination products of thyroid hormones in the rainbow trout, Oncorhynchus mykiss. Gen Comp Endocrinol 85:367-375.

Wright GM, Youson JH. 1976. Transformation of the endostyle of the anadromous sea lamprey, Petromyzon marinus L. during metamorphosis: I. Light microscopy and autoradiography with ${ }^{125}$ I. Gen Comp Endocrinol 30:243-257.

Wright GM, Youson JH. 1977. Serum thyroxine levels in larval and metamorphosing anadromous sea lamprey, Petromyzon marinus. J Exp Zool 202:27-32.

Wright GM, Filosa MF, Youson JH. 1980. Immunocytochemical localization of thyroglobulin in the transforming endostyle of anadromous sea lampreys, Petromyzon marinus L., during metamorphosis. Gen Comp Endocrinol 42:187-194.

Youson JH. 1997. Is lamprey metamorphosis regulated by thyroid hormones? Am Zool 37:439-460.
Youson JH, Connelly KL. 1978. Development of longitudinal muscle folds in the intestine of the lamprey during metamorphosis. Can J Zool 56:2364-2371.

Youson JH, Potter IC. 1979. A description of the stages of metamorphosis in the anadromous sea lamprey, Petromyzon marinus L. Can J Zool 57:1808-1817.

Youson JH, Horbert WR. 1982. Transformation of the intestinal epithelium of the larval anadromous sea lamprey, Petromyzon marinus L., during metamorphosis. J Morphol 171:89-117.

Youson JH, Holmes JA, Guchardi J, Seelye JG, Beaver RE, Gersmehl JE, Sower SA, Beamish FWH. 1993. The importance of condition factor and the influence of water temperature and photoperiod in metamorphosis of sea lampreys, Petromyzon marinus. Can J Fish Aquatic Sci 50:2448-2456.

Youson JH, Plisetskaya EM, Leatherland JF. 1994. Concentrations of insulin and thyroid hormones in the serum of land-locked sea lampreys (Petromyzon marinus) of three larval year classes, larvae exposed to two temperature regimes, and both during and after metamorphosis. Gen Comp Endocrinol 94:294-304.

Youson JH, Holmes JA, Leatherland JF. 1995. Serum concentrations of thyroid hormones in $\mathrm{KClO}_{4}$-treated larval sea lampreys (Petromyzon marinus L.). Comp Biochem Physiol 111C:265-270.

Youson JH, Manzon RG, Peck BJ, Holmes JA. 1997. Effects of exogenous thyroxine $\left(\mathrm{T}_{4}\right)$ and triiodothyronine $\left(\mathrm{T}_{3}\right)$ on spontaneous metamorphosis and serum $\mathrm{T}_{4}$ and $\mathrm{T}_{3}$ levels in immediately premetamorphic sea lampreys, Petromyzon marinus. J Exp Zool 279:145-155. 